\title{
Asidik Stresin Triploid ve Diploid Gökkuşağı Alabalığı (Oncorhynchus mykiss)'nın Hematolojik, İmmunolojik Ve Biyokimyasal Kan Parametreleri Üzerine Etkileri
}

\begin{tabular}{|c|c|}
\hline Araştırma / Research & \\
\hline $\begin{array}{l}\text { Geliş Tarihi / Received } \\
\text { 10.06.2017 }\end{array}$ & $\begin{array}{c}\text { Sevdan YILMAZ*, Ekrem Şanver ÇELIK, } \\
\text { Osman Nezih KENANOĞLU, Sebahattin ERG ÜN }\end{array}$ \\
\hline $\begin{array}{l}\text { Kabul Tarih / Accepted } \\
09.10 .2017\end{array}$ & Çanakkale Onsekiz Mart Üniversitesi, Deniz Bilimleri ve Teknolojisi \\
\hline $\begin{array}{l}\text { DOI } \\
10.28955 / \text { alinterizbd.320262 }\end{array}$ & $\begin{array}{l}\text { Fakültesi, Çanakkale-Türkiye } \\
\text { Fo_nosta. }\end{array}$ \\
\hline $\begin{array}{l}\text { ISSN 2564-7814 } \\
\text { e-ISSN 2587-2249 }\end{array}$ & 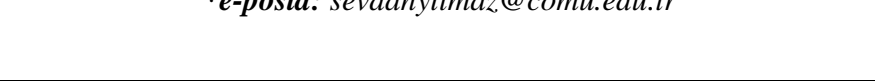 \\
\hline
\end{tabular}

Öz: Gökkuşağı alabalıklarında erken olgunluğa ulaşma metabolik enerjinin somatik büyümeden üremeye yönlendirilmesi sonucu et kalitesinin ve görünümünün bozulması nedeniyle balık üretim endüstrisi için ekonomik bir kayıptır. Triploid balık üretimi bu durumu tamamen ortadan kaldırmasa da büyük ölçüde azaltmaktadır. Ancak triploid balıkların diploidlere oranla yetiştiricilik şartlarından kaynaklı çeşitli stres faktörlerine karşı dayanıklılıkları tartı̧̧ma konusudur. Asidik strese; asit yağmurları, asidik kirleticiler ve asidik pis suların yanı sıra yetiştiricilik şartlarında artan stok yoğunluğu da neden olabilmektedir. Asidik suların balıklar üzerinde olumsuz etkileri olduğu bilinmektedir. Bu çalışmada asidik strese maruz bırakılan diploid ve triploid gökkuşağı alabalıklarının, Oncorhynchus mykiss hematolojik, immunolojik ve serum biyokimyasal parametrelerindeki değişimler incelenmiş̧ir. Asidik stres için balıklar asidik suya (pH 5,2) 4 gün maruz bırakılmışıtır. Elde edilen sonuçlar değerlendirildiğinde kırmızı kan hücre sayısı, hematokrit, hemoglobin, ortalama eritrosit hacmi, ortalama eritrosit hemoglobini, ortalama eritrosit hemoglobin konsantrasyonu, glikoz, total protein, albumin, globulin, trigliserit ve kolesterol diploid ve triploid balıklarda asidik stresten etkilenmemiş̧tir. Fakat, asidik stres diploid balıklarda NBT, lizozim ve myeloperoksidaz aktivitelerinde artışa neden olmuştur. Proje sonucunda bazı spesifik olmayan immun parametrelerinin triploid balıklarda asidik sudan etkilenmediği tespit edilmiştir.

Anahtar Kelimeler: Triploid, diploid, Rainbow trout, spesifik olmayan immun parametreleri, hematoloji, biyokimya

\section{The Effect of Acidic Stress on Hematological, Immunological and Biochemical Parameters in Triploid and Diploid Rainbow Trout (Oncorhynchus mykiss)}

\begin{abstract}
Early maturity in rainbow trout (Oncorhynchus mykiss) is an economic loss for fish production industry since flesh quality and appearance get deformed as metabolic energy is directed from somatic growth into reproduction. Triploid fish production dramatically reduces this situation, even if it does not fully wipe it out. However, the resistance of triploid fish against different stress factors resulted from aquaculture conditions is contentious compared to diploids. Acidic stress results not only from acid rains, acidic polluters and acidic waste water, but it might also result from increasing stock density under aquaculture circumstances. It is already known that acidic water has negative effects on fish. The present study investigated the effect of acidic stress on haematological, immunological and serum biochemical variables of the diploid and triploid rainbow trout, Oncorhynchus mykiss. Acidic stress was achieved by exposing the sampled fish to acidic water ( $\mathrm{pH}$ 5.2) for 4 days. Results showed that the red blood cell count, hematocrit, hemoglobin concentration, mean corpuscular volume, mean corpuscular $\mathrm{Hb}$, and mean corpuscular $\mathrm{Hb}$ concentration, glucose, total protein, albumin, globulin, triglyceride and cholesterol were not significantly affected by acidic stress in diploid and triploid fish. However, an acidic stress caused an increase in the NBT, lysozyme and myeloperoxidase activity of diploid fish. This study results indicate that the some non-specific immune functions of triploid rainbow trout did not affect by acidic water.
\end{abstract}

Keywords: Triploid, Rainbow Trout, Non-Specific Immune Functions, Hematology, Biochemistry 


\section{GIiRIS}

Balık yetiştiriciliğinde triploid balık üretimi çok sık uygulanan yöntemlerden birisidir (Dunham, 2004). Triploid fertler doğal olarak nesil veremeyen, kısır fertler olduğu için; normal diploid fertlere göre cinsel olgunluk döneminde daha hızlı büyürler, yaşama oranları daha yüksektir, normal fertlerin üreme sonrası maruz kaldıkları hastalıklara yakalanmazlar ve metabolizma enerjisinin gonad gelişimi için harcayacakları kısmını büyümeye sarf ederler (Kankaya, 1998; Vicdanlı, 2007). Örneğin; Bye ve Lincoln (1986) iki yaşına ulaşan diploid Oncorhynchus mykiss'de büyümenin yavaşladığını; triploid bireylerin ise diploidlere nazaran daha büyük olduğunu belirtmişlerdir.

Triploid organizmanın kısır olması ve doğal popülasyona kaçmasıyla oluşacak genetik etkinin sınırlanmasından dolayı çeşitli uluslararası organizasyonlar (NASCO, FAO, ICES) tarafından yetiştiricilikte ve balıklandırma çalışmalarında kullanılması tavsiye edilmektedir (Aydın, 2008). Ayrıca Avrupa Birliği mevzuatına göre (90/220/CEE 23 Nisan 1990) triploid bireylerin, genetiği değiştirilmiş organizma (GDO) olarak düşünülmemesi triploid balık üretimini olumlu yönde etkilemektedir (Piferrer ve ark., 2006).

Su ürünleri yetiştiriciliğinde triploid uygulamalar birçok araştırıcı tarafından çalışılmış, özellikle O. mykiss'de büyüme oranı ve et kalitesi açısından olumlu sonuçlara ulaşıldığı belirtilmiştir (Lincoln ve Scott, 1984; Kim ver ark., 1988; Sheehan ve ark., 1999; Poontawee ve ark., 2007). Bu tür olumlu sonuçlarla birlikte, triploid üretimin uygulama maliyetinin düşük olması, günümüzde ticari işletmelerin bu konuya olan ilgisini daha da arttırmaktadır. Ancak, triploid teknolojisi çok uzun yıllardır yapılmasına rağmen triploid balıkların diploid balıklara göre sağlık karakteristikleri, çevresel strese tepkileri ve hastalık dirençleri konusunda çok az bilgi mevcuttur. Bazı çalışmalarda triploid balıkların diploidlere oranla hastalıklara ve çevresel şartlara daha az direnç gösterdikleri tespit edilmiştir. Örneğin triploid coho salmonlarının (Oncorhynchus kisutch) vibriosis patojenine karşı diploid balıklardan daha az direnç gösterdikleri bildirilmiştir (Jhingan ve ark., 2003). Ancak bu durum patojen türüne göre değişim gösterebilmektedir. Chinook salmonlarında (Oncorhynchus tshawytscha) triploid bireylerin Renibacterium salmoninarum patojenine karşı diploid bireylere oranla daha az dirençli oldukları bulunurken Vibrio anguillarum patojenine karşı diploid ve triploid bireylerin yaşama oranları benzer bulunmuştur. Triploid gökkuşağı alabalığı üretimi her ne kadar üreme enerjisinin büyümeye aktarılmasından dolayı avantajlı gözükse de yetiştiricilik şartlarından kaynaklı çeşitli stres faktörlerine karşı dayanıklılıkları tartışma konusudur. Örneğin sıcaklık stresine maruz bırakılan diploid ve triploid gökkuşağı alabalıklarının yaşama oranı ve büyüme performansı triploid olanlarda önemli derecede düşüş göstermiştir (Ojolick ve ark., 1995). Asidik strese; asit yağmurları, asidik kirleticiler ve asidik pis sularla birlikte yetiştiricilik şartlarında artan stok yoğunluğu ve besleme sırasında artan serbest CO2 salınımıda neden olabilmektedir. Asidik suların balıklarda DNA hasarına ve oksidatif strese neden olduğu bilinmektedir (Mai ve ark., 2010). Bu nedenle gerek yetiştiricilik şartlarından gerekse de çevresel etkilerden kaynaklanan asidik stresin diploid ve triploid balıklar üzerindeki etkisinin bilinmesi önem arz etmektedir. Ancak asidik stresin diploid ve triploid gökkuşağı alabalıklarının kan parametreleri üzerine etkileriyle ilgili bir çalışmaya literatürde rastlanılmamıştır.

Bu çalışmada asidik strese maruz bırakılan diploid ve triploid gökkuşağı alabalıklarının hematolojik, immunolojik ve serum biyokimyasal parametrelerindeki değişimler incelenmiştir.

\section{MATERYAL VE YÖNTEM \\ Materyal \\ Balık ve Triploidizasyon}

Denemede kullanılan 2,5- 3 yaş ve 2-3 kg ağırlığındaki O. mykiss anaçları Çanakkale'nin Bayramiç ilçesindeki Evciler Tarımsal Kalkınma Kooperatifinden elde edilmiştir. Üretim tesisine gelen kaynak suyunun sıcaklığ $19 \pm 1{ }^{\circ} \mathrm{C}$ olarak ölçülmüştür. Yumurta verimi ve sperm kalitesi yüksek olan $\mathrm{O}$. mykiss dişi ve erkek anaçları arasından, sağım için 2 adet dişi, 6 adet erkek seçilmiştir. Kuru yöntem ile gerçekleştirilen dölleme işleminde, temiz plastik bir kap içerisine önce dişilerin yumurtaları, ardından erkeklerin spermleri sağılmış ve yavaşça karıştırılmıştır. Döllenmesi için $5 \mathrm{dk}$. bekletilen yumurtalar süre sonunda temiz su ile yıkanarak; fazla spermden, döllenmemiş yumurtalardan ve yumurta kalıntılarından arındırılmış, $10{ }^{\circ} \mathrm{C}$ 'lik suda $10 \mathrm{dk}$. bekletilerek su alıp şişmesi sağlanmıştır. Devamında döllenmiş yumurtalara daha önce laboratuarlarımızda elde edilen optimumum triploidi oranının elde edildiği $26^{\circ} \mathrm{C}$ de termostatlı su 1sıtıcısı (Heidolph) yardımıyla 15 dakika 1sı şoku uygulanmıştır (Kenanoğlu ve ark., 2012). Diploid balıklarda triploid balıklarla aynı anaçların yumurtaları ikiye bölünerek ve bu yumurtalara 1sı şoku uygulanmayarak elde edilmiş̧ir. 
Isı şoku uygulanarak triploid yapılan ve triploid yapılmayan diploid yumurtalar Evciler Tarımsal Kalkınma Kooperatifindeki kuluçka dolaplarına yerleştirilmiştir. Yavrular yem almaya başladıktan sonra Çanakkale Onsekiz Mart Üniversitesi, Deniz Bilimleri ve Teknolojisi Fakültesi, Canlı Kaynaklar Laboratuarında yer alan kapalı devre filtrasyon sistemine sahip 140 L hacmindeki 12 adet fiberglas tanka yerleştirilmişlerdir. Balıklar ağırlıkları yaklaşık $25 \mathrm{~g}$ oluncaya kadar büyütülmüştür. Büyüme döneminde otomatik zamanlayıcılar yardımıyla 12 saat aydınlık; 12 saat karanlık fotoperiyodu uygulanmıştır. Büyütülen balıklar arasından asidik stres denemesi için rastgele 180 adet balık $(25,09 \pm 0,6)$ seçilmiştir.

\section{Yöntem}

\section{Asidik stres uygulaması}

Asidik strese maruz kalan ve kalmayan balıkların denemeleri birbirinden bağımsız ve hava taşı ile havalandırması yapılan 12 adet 140 L hacmindeki fiberglas tanklarda 3 tekrarlı (4 grup X 3 tekrar $=12$ tank, 15 balık/tank) olacak şskilde 4 gün süreyle yürütülmüştür. Deney süresince balıklara yem verilmemiş ve günlük olarak \%15 su değişimi yapılmıştır. Deney prosedürü gereği (yarı-statik) filtrasyon yapılmadığından stok miktarı düşük $(\sim 2,7 \mathrm{~kg}$ balık/ton) tutulmuştur. Asidik strese maruz kalan balıkların su ortamının pH değeri \%10 luk sülfirik asit ile 5,2 olana kadar kademeli olarak azaltılmıştır. Su değişimleri yapılırken ilave edilecek suyun $\mathrm{pH}$ değeri önceden 5,2 olacak şekilde ayarlanmış ve deney tanklarına ilave edilmiştir. Asidik strese maruz kalmayan balıklara $\mathrm{pH}$ değişimi dışında aynı prosedürler uygulanmıştır. Strese maruz kalmayan balıkların ortalama $\mathrm{pH}$ değeri $7,8 \pm 0,2$ ve tüm denemelerde suyun sıcaklığ $15 \pm 1{ }^{\circ} \mathrm{C}$ ve oksijeni $7,9 \pm 2 \mathrm{mg} / 1$ olarak ölçülmüştür. Ölçümlerde YSI 550 DO Oksijen metre, HANNA (HI 2221) masa üstü pH metre ve dijital termometre kullanılmıştır. Deneme sonunda balıklarda aşağıdaki analizler yapılarak asidik su ortamının triploid ve diploid gökkuşağı alabalığı yavrularının hematolojik, immunolojik ve biyokimyasal kan parametreleri üzerine etkileri araştırılmıştır.

\section{Balıklardan kan örneklerinin alınması}

Balıklar, doğal bir ürün olan ve yaygın olarak kullanılan karanfil yağı 20 mg/mL (Iversen ve ark., 2003) ile bayıltılmışlardır. Kana mukoza karışmaması için alkolle anal yüzgecin hemen arka kısmı iyice temizlendikten sonra en kısa süre içerisinde, 5 ml'lik plastik enjektörle kaudal venadan girilerek balığa zarar vermeden, 500-600 $\mu \mathrm{L}$ kan alınmıştır. Alınan kan örnekleri K3EDTA ve jelli serum tüplerine konularak hematolojik, immunolojik ve biyokimyasal analizleri yapıllmıştır.

\section{Hematolojik analizler}

Hematolojik analizlerden kırmızı kan hücre sayısı (RBC), hematokrit oranı (Hct), hemoglobin değeri $(\mathrm{Hb})$, ortalama eritrosit hacmi (MCV), eritrosit başına düşen ortalama hemoglobin $(\mathrm{MCH})$ ve eritrosit başına düşen ortalama hemoglobin (MCHC) analizleri hemogram cihazı (Sinnowa marka HB 7021) yardımıyla yapılmıştır. Bu cihazın alabalıklar için kalibrasyonu daha önce laboratuarlarımızda manüel yöntemler kullanılarak yapılmıştır.

\section{Biyokimyasal analizler}

Biyokimyasal analizler için alınan kan $5000 \mathrm{~g}$ devirde 10 dakika santrifüj edilip kan serumu ayrıldıktan sonra daha önce balık çalışmalarında kullanılmış olan ticari kit (Bioanalytic) kullanılarak spektrofotometrik olarak yapılmıştır (Yılmaz ve Ergün 2012). Denemede glikoz (GLI), albumin (ALB), globulin (GLO), toplam protein (TPROT), trigliserit (TRI) ve kolesterol (KOL) biyokimyasal parametreleri belirlenmiştir.

\section{İmmunolojik Analizler}

NBT analizi

NBT analizi için $100 \mu \mathrm{l}$ kan örneği NBT solüsyonu eşliğinde 30 dakika inkübasyona bırakılmıştır. Sonrasında bu karışımdan $50 \mu$ alınarak N,N-dimetil formamid bulunan tüpe ilave edilmiştir. Devamında santrifüj edilen tüpler $1 \mathrm{ml}$ 'lik spektrofotometre küvetinde $540 \mathrm{~nm}$ 'de okunmuştur. NBT aktivitesi mg NBT formazan/ml olarak hesaplanmıştır (Siwicki ve Anderson, 1993).

\section{Lizozim aktivitesi}

Lizozim aktivitesinin tespit edilmesi için $25 \mu \mathrm{l}$ serum örneği üzerine $175 \mu 1$ Micrococcus lysodeikticus çözeltisi $(\% 0,09 \mathrm{NaCl}$ içeren $0,1 \mathrm{M}$ fosfat/sitrat tampon çözeltisi, $\mathrm{pH} 5,8)$ eklenerek 0,5. ve 4.5 dakikalarda $450 \mathrm{~nm}$ ' de spektrofotometrede okumalar yapılmıştır. Standart olarak Lysozyme from chicken egg white (L6876 Sigma) kullanılmıştır. Analiz sonuçları $\mu \mathrm{g} / \mathrm{ml}$ olarak hesaplanmıştır (Ellis, 1990). 


\section{Myeloperoksidaz aktivitesi}

Myeloperoksidaz aktivitesi literatürde bildirilen metotlarda bazı değişiklikler yapılarak analiz edilmiştir (Quade ve Roth 1997; Kumari ve Sahoo 2006). Analiz için $10 \mu \mathrm{l}$ serum örneği $90 \mu \mathrm{l}$ HBSS (Hank's Balanced Salt Solution, Sigma H6648) solüsyonu ile seyreltilmiştir. Devamında bu karışıma 3,3',5,5'-tetramethylbenzidine dihydrochloride ve hidrojen peroksit içeren solüsyon ilave edilerek reaksiyon 2 dakika sonra $35 \mu \mathrm{l}$ sülfirik asitle durdurulmuş ve $450 \mathrm{~nm}$ ' de spektrofotometrede okumalar yapılmıştır.

\section{İstatistiksel Analizler}

$\mathrm{Bu}$ çalışmada deneme gruplarından elde edilen kan parametre verileri arasındaki ilişkilerin değerlendirilmesi amacıyla Kruskal-Wallis ve Dunn's çoklu karşılaştırma testi NCSS istatistik paket programı kullanılarak yapılmıştır.

\section{ARAŞTIRMA BULGULARI VE TARTIŞMA}

\section{Hematolojik Bulgular}

Çalışma sonucunda elde edilen hematolojik analiz bulguları Çizelge 1. de gösterilmiştir. Elde edilen sonuçlara bakıldığında $\mathrm{RBC}, \mathrm{Hct}, \mathrm{Hb}, \mathrm{MCV}, \mathrm{MCH}$ ve $\mathrm{MCHC}$ parametrelerinin deneme grupları arasında istatistiksel açıdan fark göstermediği bulunmuştur $(\mathrm{P}>0,05)$.

Çizelge 1. Asidik strese maruz bırakılan ve bırakılmayan diploid ve tiriploid gökkuşağı alabalıklarında hematolojik değişimler

\begin{tabular}{lcccc}
\hline & \multicolumn{3}{c}{ DENEME GRUPLARI } \\
\hline & Diploid & Triploid & Diploid & Triploid \\
\hline RBC $\left(\mathbf{x 1 0}^{\mathbf{6}} \mathbf{~ m m}^{\mathbf{3}}\right)$ & $3,25 \pm 0,20$ & $3,15 \pm 0,10$ & $3,04 \pm 0,02$ & $2,97 \pm 0,11$ \\
\hline $\mathbf{H b}(\mathbf{g} / \mathbf{d L})$ & $6,20 \pm 0,10$ & $5,22 \pm 0,15$ & $6,24 \pm 0,11$ & $5,84 \pm 0,33$ \\
\hline Hct $\mathbf{\%})$ & $37,10 \pm 1,16$ & $34,45 \pm 0,21$ & $36,70 \pm 1,41$ & $35,44 \pm 1,40$ \\
\hline MCV (fL) & $114,15 \pm 5,16$ & $109,37 \pm 1,90$ & $120,72 \pm 5,29$ & $119,33 \pm 5,10$ \\
\hline MCH (pg) & $19,08 \pm 0,51$ & $16,57 \pm 0,12$ & $20,53 \pm 1,01$ & $19,66 \pm 1,19$ \\
\hline MCHC (\%) & $16,71 \pm 0,90$ & $15,15 \pm 0,95$ & $17,00 \pm 0,99$ & $16,48 \pm 0,87$ \\
\hline
\end{tabular}

$\mathrm{n}=9$, ortalama \pm standart hata.

Kalkan balıklarında (Psetta maxima) yapılan bir çalışmada diploid ve triploid bireylerin hematolojik parametrelerindeki değişim incelendiğinde eritrosit miktarının (RBC) triploid balıklarda daha düşük olduğu tespit edilmiştir (Budiño ve ark., 2006; Benfey ve Biron 2000). Benzer olarak triploid alabalıklarda RBC ve Hb miktarının triploid balıklardan daha düşük olduğu bildirilmiştir (Dorafshan ve ark., 2010). Ancak çalışmamızda olduğu gibi triploid ve diploid alabalıkların Hb değerlerinde bir faklılık olmadığını bildiren çalışmalarda mevcuttur (Han ve ark., 2007). Farklı bir çalışmada akut stresin alabalıklar üzerindeki etkisi araştırılmış $\mathrm{Hb}$ ve Hct değerlerinin çalışmamızda olduğu gibi diploid ve triploid alabalıklarda benzer olduğu görülmüştür (Benfey ve Biron 2000). Çalışmalarda diploid ve triploid balıkların hematolojik parametrelerinde elde edilen farklı sonuçların, triploid balık üretim tekniklerinde kullanılan farklı yöntemlerden kaynaklandığı düşüncesindeyiz.

\section{Serum Biyokimya Bulguları}

Çalışma sonucunda elde edilen biyokimyasal analiz bulguları Çizelge 2. de gösterilmiştir. Serum biyokimyasal parametrelerinden glikoz, total protein, albumin, globulin, trigliserit ve kolesterol değerlerinin gruplar arasında istatistiksel açıdan fark göstermediği bulunmuştur $(\mathrm{P}>0,05)$. 
Çizelge 2. Asidik strese maruz bırakılan ve bırakılmayan diploid ve tiriploid gökkuşağı alabalıklarının Alınteri serum biyokimyasındaki değişimler

\begin{tabular}{lcccc}
\hline \multicolumn{4}{c}{ DENEME GRUPLARI } \\
\hline & Diploid & Triploid & Diploid & Triploid \\
\hline Glikoz (mg/dL) & $35,21 \pm 5,10$ & $27,06 \pm 5,66$ & $34,96 \pm 3,41$ & $42,14 \pm 4,24$ \\
\hline Total Protein (g/dL) & $2,51 \pm 0,27$ & $2,84 \pm 0,24$ & $2,84 \pm 0,19$ & $2,96 \pm 0,27$ \\
\hline Albumin (g/dL) & $0,48 \pm 0,05$ & $0,54 \pm 0,06$ & $0,52 \pm 0,04$ & $0,61 \pm 0,04$ \\
\hline Globulin (g/dL) & $2,03 \pm 0,27$ & $2,30 \pm 0,27$ & $2,32 \pm 0,19$ & $2,36 \pm 0,28$ \\
\hline Trigliserit (mg/dL) & $40,43 \pm 4,14$ & $37,45 \pm 4,85$ & $26,79 \pm 3,32$ & $29,06 \pm 4,04$ \\
\hline Kolesterol (mg/dL) & $107,20 \pm 10,93$ & $72,16 \pm 6,41$ & $68,00 \pm 8,03$ & $85,10 \pm 10,39$ \\
\hline
\end{tabular}

$\mathrm{n}=9$, ortalama \pm standart hata

Çalışmamızla benzer olarak Atlantic salmonlarında (Salmo salar) serum protein miktarının (Langston ve ark., 2011) ve gökkuşağı alabalıklarında glikoz miktarının (Benfey ve Biron 2000) diploid ve triploid balıklarda benzer olduğu tespit edilmştir.

\section{İmmünolojik Bulgular}

Çalışma sonucunda elde edilen immonolojik analizlerden NBT testi sonuçları Şekil 1. de gösterilmiştir. Asidik strese maruz bırakılmayan diploid ve triploid balıkların NBT testi sonuçları arasında istatistiksel açıdan bir fark görülmezken $(\mathrm{P}>0,05)$, asidik strese maruz kalan diploid balıkların NBT değerinin asidik strese maruz bırakılmayan diploid ve triploid balıklarınkinden istatistiksel olarak daha yüksek olduğu bulunmuştur $(\mathrm{P}<0,05)$. Ancak asidik strese maruz kalan diploid ve triploid balıkların NBT değerinin benzer olduğu görülmektedir $(\mathrm{P}>0,05)$.

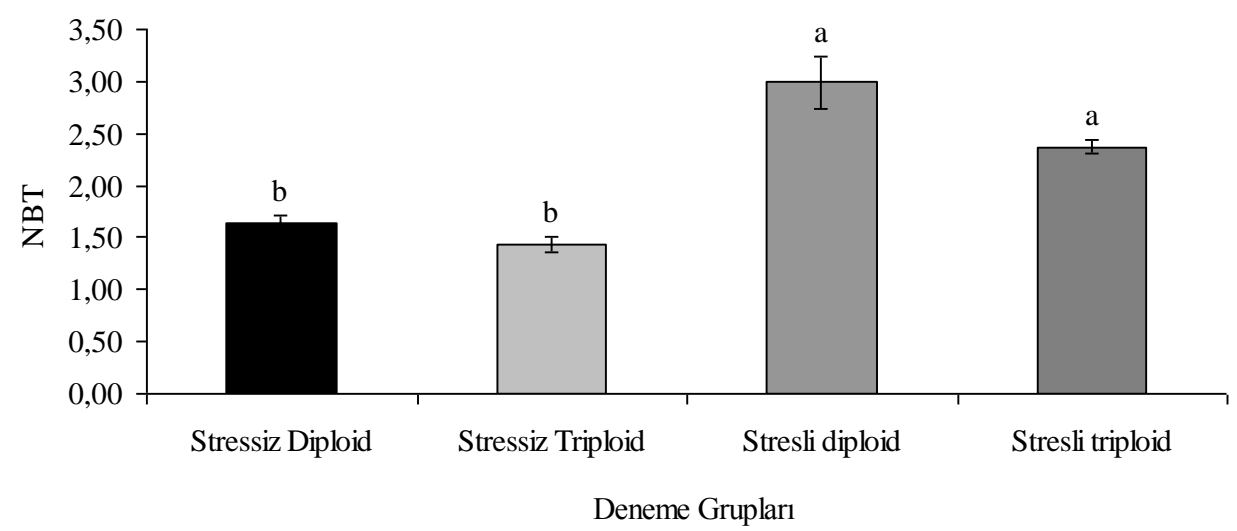

Şekil 1. Asidik strese maruz bırakılan ve bırakılmayan diploid ve tiriploid gökkuşağı alabalıklarının NBT (mg NBT formazan/mL) değerlerindeki değişimler

Çalışma sonucunda elde edilen immonolojik analizlerden lizozim testi sonuçları Şekil 2. de gösterilmiş̧ir. Asidik strese maruz bırakılmayan diploid ve triploid balıkların lizozim testi sonuçları arasında istatistiksel açıdan bir fark tespit edilmemiştir $(\mathrm{P}>0,05)$. Ancak asidik strese maruz kalan diploid balıkların lizozim değerinin asidik strese maruz bırakılmayan diploid ve triploid balıklarınki ile asidik strese maruz bırakılan triploid balıklarınkinden istatistiksel olarak daha yüksek olduğu bulunmuştur $(\mathrm{P}<0,05)$. 


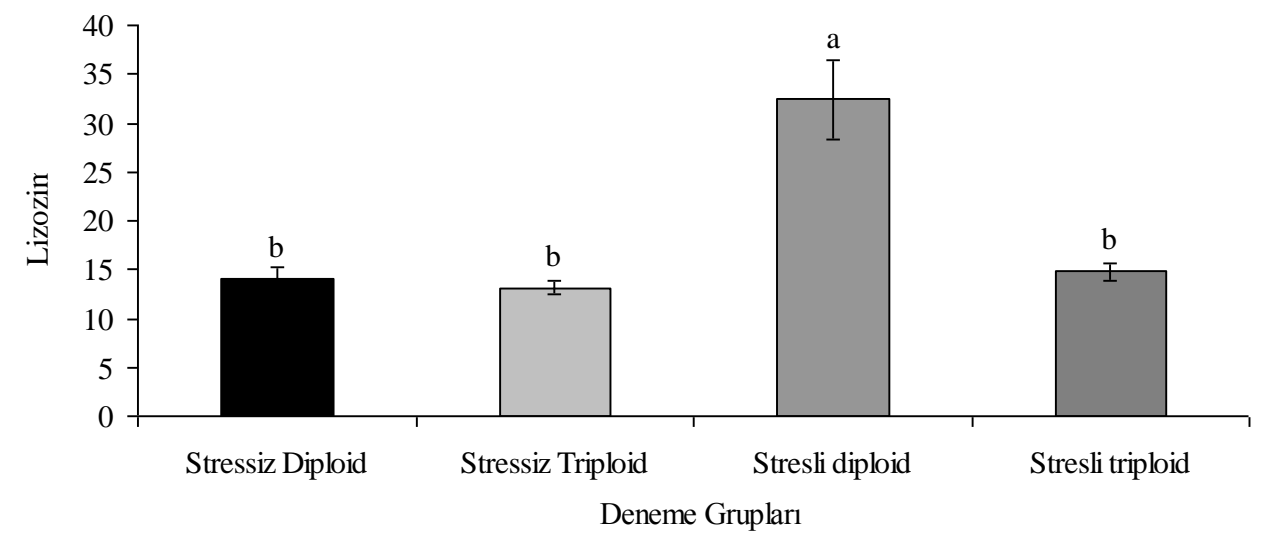

Şekil 2. Asidik strese maruz bırakılan ve bırakılmayan diploid ve tiriploid gökkuşağı alabalıklarının lizozim $(\mu \mathrm{g} / \mathrm{mL})$ değerlerindeki değişimler

Çalışma sonucunda elde edilen immonolojik analizlerden MPO testi sonuçları Şekil 3. de gösterilmiştir. Asidik strese maruz bırakılmayan diploid ve triploid balıkların MPO testi sonuçları arasında istatistiksel açıdan bir fark tespit edilmemiștir $(\mathrm{P}>0,05)$. Asidik strese maruz kalan diploid balıkların MPO değerinin asidik strese maruz bırakılmayan diploid ve triploid balıklarınki ile asidik strese maruz bırakılan triploid balıklarınkinden istatistiksel olarak daha yüksek olduğu tespit edilmiştir $(\mathrm{P}<0,05)$.

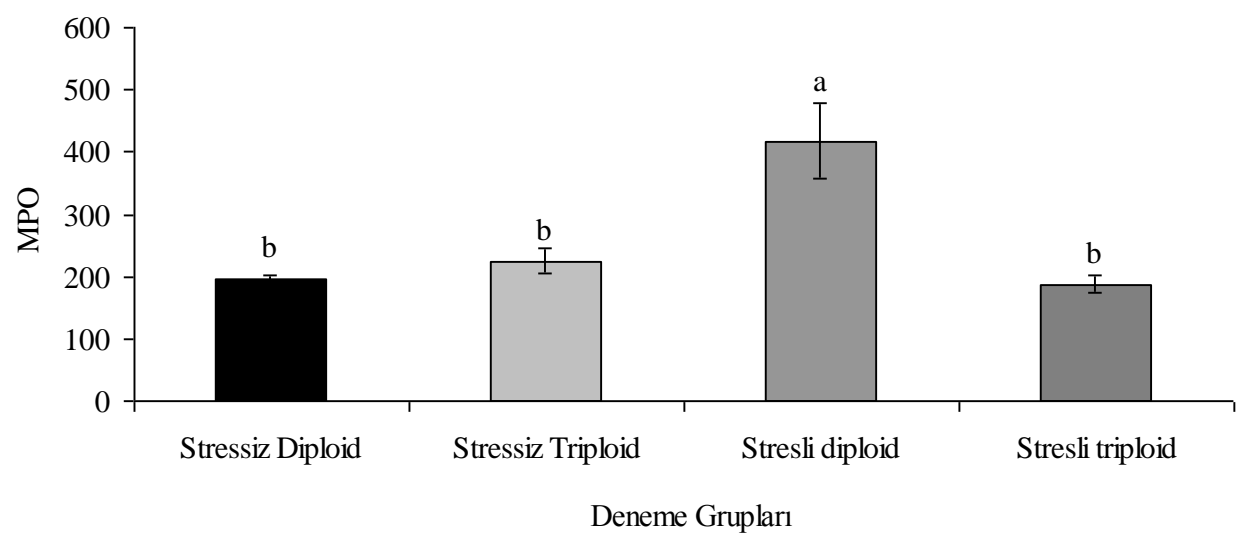

Şekil 3. Asidik strese maruz bırakılan ve bırakılmayan diploid ve tiriploid gökkuşağı alabalıklarının MPO (U/L) değerlerindeki değişimler

Çalışmamızda diploid ve triploid balıkların immunolojik parametrelerine benzer olarak, kalkan balıklarında (Psetta maxima) yapılan bir çalışmada diploid ve triploid bireylerin immunolojik parametreleri (lizozim, NBT miktarı, fagositik aktivite, complement) karşılaştırılmış ve gruplar arasında istatistiksel açıdan bir farklılık olmadığı bulunmuştur (Budiño ve ark., 2006). Ancak farklı bir çalışmada triploid Atlantic salmon (S. salar) balıklarının NBT (respiratory burst) aktivitesinin diploidlere göre daha yüksek olduğu bildirilmiştir (Chalmers ve ark., 2016). Çalışmalar arasındaki farklılıkların balık türü, yetiştiricilik şartları ve/veya triploidizasyon işlemlerinin farklılıklarından kaynaklandığı düşüncesindeyiz.

Stres durumunda ise triploid ve diploid balıkların bazı immunolojik parametrelerinde farklılıklar olduğu rapor edilmiştir. Örneğin deneysel olarak amoebik solungaç hastalığına (Neoparamoeba perurans) maruz bırakılan triploid ve diploid Atlantic salmon (Salmo salar) balıklarının immunolojik parametrelerinden komplement ve anti-proteaz aktivitelerinin benzer, ancak lizozim aktivitesinin hastalıklı diploid balıklarda triploid balıklardan daha yüksek olduğu bildirilmiştir (Chalmers ve ark., 2017). Strese maruz kalan triploid balıklarda lizozim ve/veya MPO aktivitelerinin diploidlere oranla düşük olması şaşırtıcıdır. $\mathrm{Bu}$ durum stres altındaki diploid ve triploid balıkların telafi mekanizmalarının farklı olması ile açıklanabilir. 


\section{SONUÇ VE ÖNERILLER}

Sonuç olarak bu çalışmada elde edilen bulgular ışığında 1sı şoku ile triploid yapılan alabalıkların diploid alabalıklara göre hematolojik ve serum biyokimyasal parametrelerinde asidik stresin ve triploidizasyonun bir etkisinin olmadığı bulunmuştur. Ancak, analiz edilen immunolojik parametrelerde asidik strese bağlı önemli değişimler gözlemlenmiş̧ir. İleriki çalışmalarda asidik strese karşı triploid balıkların meydana getirdiği telafi edici mekanizmaların daha detaylı (moleküler düzeyde) araştrılması gerektiği düşüncesindeyiz.

\section{TEŞEKKÜR}

Bu çalışma Çanakkale Onsekiz Mart Üniversitesi Bilimsel Araştırma Projeleri Koordinasyon Birimi tarafindan FBA-2014-354 no'lu proje ile desteklenmiştir.

\section{KAYNAKLAR}

Aydın, İ. 2008. Karadeniz Kalkan Balığı (Psetta maxima Linnaeus,1758) Yumurta kalitesinin blastomer morfolojisi ile tahmin edilmesi ve triploid uygulamasinin yumurta kalitesine etkilerinin belirlenmesi. Yüksek Lisans Tezi. Rize Üniversitesi, Rize.

Benfey, T. J., and Biron, M. 2000. Acute stress response in triploid rainbow trout (Oncorhynchus mykiss) and brook trout (Salvelinus fontinalis). Aquaculture, 184: 167-176.

Budiño, B., Cal, R. M., Piazzon, M. C., and Lamas, J. 2006. The activity of several components of the innate immune system in diploid and triploid turbot. Comparative Biochemistry and Physiology Part A: Molecular and Integrative Physiology, 145: 108-113.

Bye, V.J. and Lincoln, R.F. 1986. Commercial methods for the control of sexual maturation in rainbow trout (Salmo gairdneri). Aquaculture, 57: 229.

Chalmers, L., Thompson, K. D., Taylor, J. F., Black, S., Migaud, H., North, B., and Adams, A. 2016. A comparison of the response of diploid and triploid Atlantic salmon (Salmo salar) siblings to a commercial furunculosis vaccine and subsequent experimental infection with Aeromonas salmonicida. Fish \& shellfish immunology, 57, 301-308.

Chalmers, L., Taylor, J. F., Roy, W., Preston, A. C., Migaud, H. and Adams, A. 2017. A comparison of disease susceptibility and innate immune response between diploid and triploid Atlantic salmon (Salmo salar) siblings following experimental infection with Neoparamoeba perurans, causative agent of amoebic gill disease. Parasitology, 144: 1229-1242.

Dorafshan, S., Kalbassi, M. R., Karimi, S. S., and Rahimi, K. 2010. Study of some haematological indices of diploid and triploid rainbow trout, Oncorhynchus mykiss. Yakhteh Medical Journal, 11: 442-447.

Dunham, R. A. 2004. Aquaculture and fisheries biotechnology: genetic approaches: CABI. ISBN 0-85199-596-9.

Ellis, A.E., 1990. Lysozyme assays, ed: Stolen JS., Fletcher TC., Anderson DP., Roberson BS., van Muiswinkel WB., NJ: SOS Publications. pp: 101-103.

Han, Y., Wang, K., Zhang, L. L., and Liu, M. 2007. Comparison on erythrocyte and some haematology indices of diploid and triploid rainbow trout (Oncorhynchus mykiss). Freshw Fish, 37: 52-55.

Iversen, M., Finstad, B., McKinley, R. S., and Eliassen, R. A. 2003. The efficacy of metomidate, clove oil, Aqui-

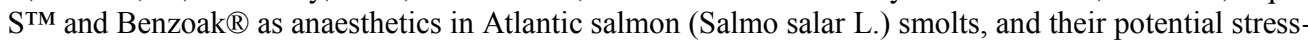
reducing capacity. Aquaculture, 221: 549-566.

Jhingan, E., Devlin, R. H., and Iwama, G. K. 2003. Disease resistance, stress response and effects of triploidy in growth hormone transgenic coho salmon. Journal of Fish Biology, 63: 806-823.

Kankaya, E., 1998. Gökkuşağı alabalığında (Oncorhynchus mykiss, W., 1792) 1sı şoku uygulamasıyla triploidi oluşturulmasi üzerine bir araştirma (Yüksek Lisans Tezi). Yüzüncü Yıl Üniversitesi, Van.

Kenanoğlu, O. N. 2012. Gökkuşağı alabalığ1 (Oncorhynchus mykiss) yumurtalarına farklı sürelerde uygulanan 1sı şokunun triploid oluşuma ve yaşama oranına etkisi. Yüksek Lisans Tezi, Çanakkale Onsekiz Mart Üniversitesi, Çanakkale.

Kim, D.S., Kim, I.B. and Baik, Y.G. 1988. Early growth and gonadal development of triploid rainbow trout (Salmo gairdneri). Journal of Aquaculture, 1: 41-55.

Kumari, J., and Sahoo, P.K. 2006. Dietary levamisole modulates the immune response and disease resistance of Asian catfish Clarias batrachus (Linnaeus). Aquaculture Research, 37: 500-509.

Lincoln, R.F. and Scott, A.P. 1984. Sexual maturation in triploid rainbow trout (Salmo gairdneri). Journal of Fish Biology, 25: 385-392.

Mai, W. J., Yan, J. L., Wang, L., Zheng, Y., Xin, Y., and Wang, W. N. 2010. Acute acidic exposure induces p53mediated oxidative stress and DNA damage in tilapia (Oreochromis niloticus) blood cells. Aquatic toxicology, 100: 271-281.

Ojolick, E. J., Cusack, R., Benfey, T. J., and Kerr, S. R. 1995. Survival and growth of all-female diploid and triploid rainbow trout (Oncorhynchus mykiss) reared at chronic high temperature. Aquaculture, 131: 177-187.

Poontawee, K., Werner, C., Müller-Belecke, A., Hörstgen-Schwark, G., and Wicke, M. 2007. Flesh qualities and muscle fiber characteristics in triploid and diploid rainbow trout. Journal of Applied Ichthyology, 23: $273-275$. 
Quade, M.J. and Roth, J.A., 1997. A rapid, direct assay to measure degranulation of bovine neutrophil primary granules. Veterinary Immunology and Immunopathology, 58: 239-248.

Sheehan, R.J., Shasteen, S.P., Suresh, A.V., Kapuscinski, A.R. and Seeb, J.E., 1999. Better growth in all-female diploid and triploid rainbow trout. Transactions of the American Fisheries Society, 128: 491-498.

Siwicki, A.K. and Anderson D.P. 1993. Immunostimulation in fish: measuring the effects of stimulants by serological and immunological methods. abstract and techniques manual presented at the Nordic symposium on fish immunology, Lysekil, Sweden, 19-22 May 1993.

Vicdanl1, S. M., 2007. Sinop yöresinde avlanan ekonomik öneme sahip bazı deniz balıklarında kromozom çalışmaları (Yüksek Lisans Tezi). Ondokuz Mayıs Üniversitesi, Samsun.

Y1lmaz, S. and Ergün, S. 2012. Effects of garlic and ginger oils on hematological and biochemical variables of sea bass Dicentrarchus labrax. Journal of Aquatic Animal Health, 24: 219-224. 